\title{
Supplier Selection Criteria used by Craft Retailers in South Africa: Influence of the Years of Buying Experience
}

\author{
Mercy Makhitha \\ Senior Lecturer: Department of Logistics, Vaal University of Technology, Private Bag X021, Vanderbijlpark, 1900 \\ Email: kmakhitha@yahoo.com or mercym@vut.ac.za
}

\section{Doi:10.5901/mjss.2014.v5n23p1660}

\section{Abstract}

\begin{abstract}
The development of the craft industry is a key strategy of the South African (SA) government for sustainable development and the creation of employment opportunities. The industry also contributes to economic growth and environmental stewardship as evidenced by government initiatives, research, projects and entities that have been initiated in support of the industry. However, craft producers lack understanding of what the craft retailers' needs are, which leads to an inability to formulate appropriate and competitive product and marketing strategies. An understanding of supplier selection criteria used by craft retailers would enable craft producers to formulate an effective marketing strategy targeted at craft retailers. The purpose of this study was to investigate the supplier selection criteria craft retailers use when evaluating craft producers as their suppliers. A survey was conducted among 233 craft retailers in SA. The research also purported to determine if the supplier selection criteria differ for craft retailers with different years of buying experience. The findings indicated that craft retailers consider quality as the most important supplier selection criteria. However, craft retailers with different years of buying experience did not differ on the importance attached to various supplier selection criteria.
\end{abstract}

Keywords: Craft retailers, craft producers, years of buying experience, supplier selection criteria, craft industry

\section{Introduction}

The craft industry is a leading component of economic growth, employment, trade, innovation and social cohesion in most developed countries (Deloitte, 2012). The industry contributes R2 billion to the gross domestic product (GDP) in the craft industry value chain (Kaiser \& Associates, 2005) and consists of over 7000 craft producer organisations (Department of Trade and Industry (DTI), 2005). The industry employs 40000 people (DED \& SEDA, 2007:23 in McCarthy \& Mavundla, 2009). The local market has shown a strong growth of between 3-4 percent annually and the sector contributes 0.14 percent of the GDP, of which R150 million is from the export sales. The number of craft producer organisations has also increased by 40 percent with an average growth of 8 percent per year, double the national average (Department of Labour, 2008).

There is an increasing demand for craft products globally, especially for home accessories and décor, gifts and products for garden and outdoor living which are simultaneously used for decorative and functional purposes (USAID, 2006). The rise in consumers' disposable incomes and the tendency to accessorise and re-style homes with unique articles are the major driving factors of the surge in demand for crafts and decorative products (Frost \& Sullivan, 2005). In SA, recent decades have seen the opening of many homeware stores such as PepHome, @Home, @Home living space, and $\mathrm{Mr}$ Price Home as well as Woolworths Artistic Collection department, which operate from inside the Woolworths branches. All these retailers sell handcrafted products, which create opportunities for craft producers targeting craft retailers.

However, craft producers face numerous marketing-related challenges in SA. They lack understanding of what the market needs, which leads to an inability to formulate appropriate and competitive product and marketing strategies (Grobler, 2005). Craft producers often sell similar products that do not address market demands and they have difficulty in accessing the markets (Makhitha \& Bresler, 2011; Hay, 2008; Department of Sports, Arts, Recreation \& Culture, 2007). Craft producers also lack skills in product design, distribution and organisation management (DTI, 2005) and possess limited knowledge of the lifestyles and product preferences of their potential customers and the promotional strategies needed to target them (Littrell \& Miller, 2001). As stated in Urban-Econ Tourism (2010), craft producers copy each other's product designs and products which lack innovativeness and uniqueness. Because they are not informed about the market and are unable to produce the quality and quantity it demands, they cannot access the retail market. The challenges widen the gap between craft producers and craft retailers, making it difficult for the craft producers to sell their 
products through craft retailers. An understanding of the supplier selection $n$ criteria used by craft retailers when selecting suppliers would assist craft producers to formulate an appropriate marketing strategy for craft producers. Literature has indicated that the buying experience of organisational buyers influence the supplier selection criteria that they use. This study will in addition to identifying the most important supplier selection criteria used by craft retailers, also determine if criteria differ for craft retailers with different years of buying experience.

\section{Supplier Selection Criteria used by Craft Retailers}

Supplier selection criteria have been the subject of investigation for more than four decades (Lin \& Wu, 2011; Kim \& Boo, 2010; Kahraman, Cebeci \& Ulukan, 2003; Da Silva, Naude \& Davies, 2001; Hansen, 2001; Pelligrini, \& Zanderighi, 2001; Wilson, 1994; Fiorito, 1990; McLaughlin \& Rao, 1989; Wagner, Ettenson \& Parish, 1989; Francis \& Brown, 1985-86 and Nilsson, 1977). The supplier selection criteria consist of a list of criteria or factors that retailers generate whenever supplier selection decisions have to be made, as well as when determining which supplier purchases will be made (Braglia \& Petroni, 2000). Criteria must be tailored to meet the needs of specific retailers, who depend on the information available about the industry (Luo, Rosenburg \& Barnes, 2009:256). They differ from one type of purchasing situation to another and also from one organisation to another (Webster \& Wind, 1996; Sheth, 1981; Dempsey, 1978).

Lin and Wu (2011) listed 28 supplier selection criteria for supermarket chains in Taiwan. The ten most important criteria, in order of importance, were procurement price, product quality, product consistency, food safety, product return and complaints policy, quantity discount and allowance, on-time delivery, professionalism of salespeople and delivery reliability. In assessing the clothing retail buyer supplier selection criteria, Da Silva Naude and Davies (2002) identified, in order of importance, quality, delivery time and cost as the most important criteria. Hansen (2001) also studied supermarket supplier selection criteria and listed high product quality, the supplier's reliability, policy regarding return/handling complaints, high service level, willingness to cooperate, ability to supply products based on demand, products certified by authorised organisation, competitive prices, broad product range and flexibility of the supplier as the ten most important criteria for supplier selection. Kim and Boo (2010) also identified products that meet current trends as one of their tem most important supplier selection criteria.

USAID (2006) listed the six most important criteria for craft retailers when evaluating suppliers. These include quality, design, price, capacity, delivery and organisation skills. The quality criteria include the quality of the materials used in the production process, the craftsmanship (how the product is made), the finish (type of polish or paint used, accuracy of colour and how finely edges are filed), the consistency (handcraft items must be consistent in design and dimensions, even though they are not identical) and the packing and shipping (whether it is well-packed, in clean materials that prevent damage and whether it is cost effective). An assessment of quality is also made by taking into consideration whether the product is handmade or mass produced. Some researchers argue that mass-produced products are not considered craft products (Luutonen, 2009).

The design, quality and price - were also identified by Design Africa (2008) as the most important criteria that craft producers can use to position themselves. Moreno and Littrell (2001) identified some product criteria that are similar to those listed by USAID (2006), such as design and stylistic qualities, while they also listed production (standardisation and individualisation), size of products, materials and function as additional criteria. According to Rogerson (2000), the ability of craft producers to innovate or produce new product designs plays an important role in facilitating and expanding market access.

Hansen (2001) studied the buying behaviour of Chinese supermarkets with specific focus on the criteria supermarkets use to evaluate suppliers. Product quality, supplier reliability and policy regarding returns/handling complaints were identified, in order of importance. The least important supplier selection criteria were the well-known brands, market promotion support and products packaged according to the retailers' requirements. Supplier selection criteria were found to differ for different products sold within the supermarkets, in different supermarkets and in different sizes of supermarkets. Competitive pricing was found to be least important for some supermarkets (Hansen, 2001). Wilson (1994) and Dempsey (1978:) listed price, quality and delivery as the most important criteria. Sternquist and Chen (2006:) found that price was an important criterion for food retailers that they investigated and that trade assistance and supplier role performance were the other important criteria that food retailers used to evaluate suppliers.

\section{Supplier Selection Criteria and Years of Buying Experience}

Literature has indicated that the number of years of buying experience influences the supplier selection criteria that retailers use (Park \& Krishna, 2001:267; Yu, Fairhurst \& Lennon, 1996:20 and Ettenson \& Wagner, 1986:58). Da Silva, 
Davies and Naude (2002) stated that buyers are not homogeneous but differ from one another in age and experience. For example, the more experienced buyers of menswear consider cost price as the most important criterion, unlike the less experienced buyers, while the less experienced buyers of household textiles, in contrast with more experienced buyers, saw cost as the most important criterion. This implies that buyers differ according to their experience in buying as well as the products they are buying.

Ettenson and Wagner (1986) indicated that supplier selection criteria differ for different types of retailers and that more experienced buyers used mark-up and sales record as the supplier selection criteria. Davies (1995 in Hansen \& Skytte, 1997) found that less experienced buyers used objective criteria such as net margins and price for delisting suppliers, unlike more experienced buyers. Park and Krishna (2001) and Yu, Fairhurst and Lennon (1996) also found that years of buying experience affect the decision on which supplier selection criteria to use when evaluating suppliers. Furthermore, Farrell (2006) found that criteria used by import buyers differed with years of buying experience. The buying experience was found to apply mainly in the rebuy situation (Mawson \& Fearene, 1997), which supports the findings that years of buying experience do not influence the criteria used by craft retailers.

From the above discussion, it was hypothesised that:

$\mathrm{H}_{0}$ There are no significant differences between craft retailers' buying experience and the importance they attach to supplier selection criteria.

$\mathrm{H}_{4}$ There are significant differences between craft retailers' buying experience and the importance they attach to supplier selection criteria.

\section{Research Methodology}

A survey was used targeted to formal craft retailers in South Africa. This included variety of craft retailers of different types and sizes, such as craft shops, small interior and gift stores, interior and decor shops, discounts retailers, clothing shops, furniture shops, museums, galleries, jewellery shops and destination retailers. A non-probability convenience sampling method was adopted, owing to the difficulties of identifying craft retailers, and the fact that there is no reliable and easily accessible database of craft retailers.

Data were collected electronically through email, as well as personally hand-delivered questionnaires to craft retailers for self-completion during November 2012 and March 2013. Over 680 questionnaires were distributed. However, 273 were completed and returned. Of the 273 questionnaires returned, only 233 were useable, giving a response rate of 34 per cent. The remaining 40 questionnaires were incomplete, with some questionnaires only half done, or missing multiple responses. These were, therefore, disregarded and not included in the analysis.

Although all the nine provinces in SA were targeted for data collection, data were only gathered from the craft retailers operating in six provinces, including: Gauteng, the Western Cape, KwaZulu-Natal, Mpumalanga, North West, and the Eastern Cape due to the low response rate and non-probability sampling. The majority of responses came from Gauteng and the Western Cape, since they house most of the major retailers' head offices, as well as the fact that craft retailing is more active in these areas. The questionnaire was pre-tested, using the participant pre-test method, with 12 craft retailers; and the wording of some questions was slightly altered - to ensure clarity.

Respondents were requested to indicate how important each of the 39 listed supplier selection criteria is on a 5 point Likert-type scale, where(1) indicated not important at all to (5) extremely important. The Cronbach's alpha for the scale was 0.90 , indicating satisfactory internal consistency reliability. Malhotra (2010) deemed a Cronbach's alpha of 0.70 to be an indication of satisfactory internal consistency reliability. No incentives were provided for participation, as participation was voluntarily.

\subsection{Ethical consideration}

The individual craft retailers did not receive any incentives; and participation was at all times voluntary.

\subsection{Data analysis}

Descriptive statistics, factor analysis and ANOVA tests were conducted; and the results are reported and discussed in the next section. 


\section{Results}

\subsection{Sample composition}

The sample population consisted of various types of retailers. Majority of craft retailers were the craft stores (44\%) followed by the destination retailers (17\%). There were also small interior/gift stores (12\%), large retailers such as clothing and décor stores (15\%) and speciality stores such as galleries, museums and jewellery shop (12). The respondents consisted of buyers, managers, owner-managers, manager-buyers, and executives responsible for buying. The owner-managers were the largest group, comprising 44 per cent $(n=101)$ of the population. Managers were the second-largest group of respondents, comprising over 18 per cent $(n=42)$ of the population. This was followed by manager-buyers, with about 14 per cent of the population $(n=31)$. Buyers made up over 12 per cent of the population $(n=28)$. The last group of respondents comprised the executives, who represented about 12 per cent of the population, consisting of 27 respondents.

The years of buying experience of the respondents varied from 1 year to 30 years. This question was answered by 222 of the total population. The years of buying experience were collapsed for statistical analysis into three groups: 0-5, $>5-10$ and $10+$ years and are depicted in Figure 1.

Figure 1: Years of buying experience

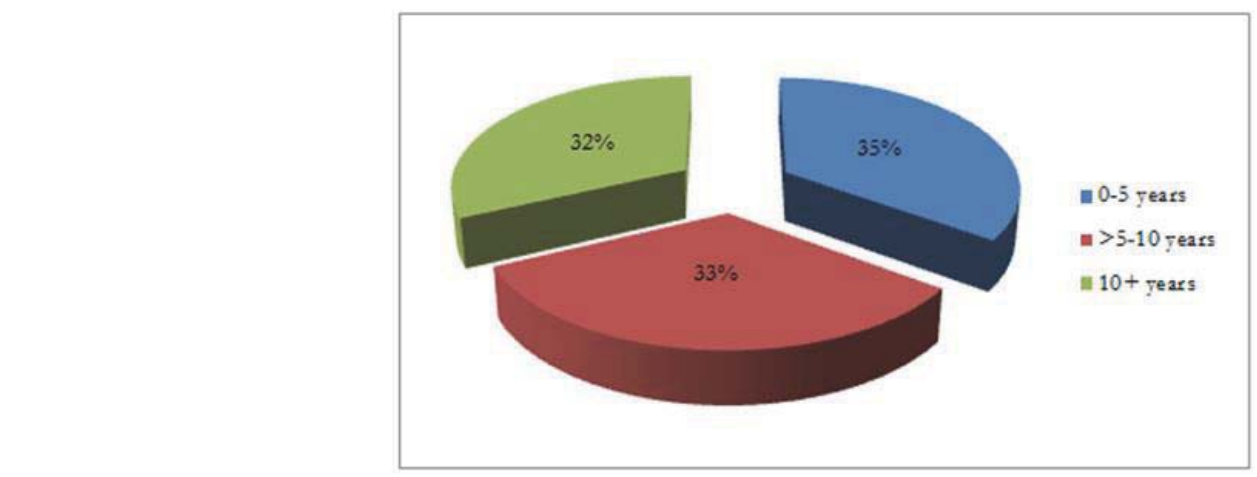

$\mathrm{N}=222$ (Missing responses $=11$ )

The majority of respondents had between one and five years of buying experience and represented $35 \%(n=78)$ of the sample, followed by those with buying experience of more than 5 and less than 10 years, representing $33 \%(n=74)$ of the sample. Those with buying experience of more than 10 years represented $32 \%(n=70)$ of the sample.

\subsection{The importance of supplier selection criteria}

An understanding of the supplier selection criteria used by craft retailers in choosing their suppliers is important for craft producers who want to sell to the craft retailers. This requires that craft producers are aware not only of the supplier selection criteria but also of the importance attached to each of the criteria. This will prepare producers to focus on those criteria that are important when selling to craft retailers and to offer craft retailers what they do want. Highlighting the supplier selection criteria according to importance, based on mean scores, will be useful for craft producers, enabling them to understand the needs and requirements of craft retailers and to use their limited resources to focus on the most important criteria. Table 1 below shows the supplier selection criteria in order of importance, based on the mean scores. 
Table 1: Importance of supplier selection criteria

\begin{tabular}{|c|c|c|c|}
\hline Order of importance & Supplier selection criteria & M & SD \\
\hline 1 & Product quality & 4.59 & 0.71 \\
\hline 2 & Product is exciting and attractive & 4.39 & 0.74 \\
\hline 3 & Product styling and design & 4.18 & 0.87 \\
\hline 4 & Product distinctiveness/unique & 4.18 & 0.90 \\
\hline 5 & Supplier's willingness to cooperate with us & 4.18 & 0.97 \\
\hline 6 & Product's sales potential, i.e. product will sell & 4.17 & 0.93 \\
\hline 7 & The ability to supply products based on our demand/requirements & 4.15 & 0.92 \\
\hline 8 & Supplier capacity, i.e. the ability to supply needed quantity & 4.13 & 0.99 \\
\hline 9 & Delivery reliability, i.e. the ability to deliver on time & 4.12 & 1.17 \\
\hline 10 & Total cost of acquiring the product & 4.08 & 0.99 \\
\hline 11 & Supplier's willingness to negotiate prices & 4.07 & 1.04 \\
\hline 12 & Supplier introduces new products or improvements from time to time & 3.91 & 1.07 \\
\hline 13 & Good product ideas that match current trends & 3.88 & 1.07 \\
\hline 14 & Ability of the product to fit in with existing ranges & 3.88 & 1.08 \\
\hline 15 & Products are handmade & 3.87 & 1.20 \\
\hline 16 & The convenience of placing orders with the supplier & 3.86 & 1.05 \\
\hline 17 & The flexibility of the supplier to accommodate our changing needs & 3.84 & 1.05 \\
\hline 18 & Established long-term relationship with the supplier & 3.80 & 1.22 \\
\hline 19 & Supplier provides new and interesting product idea/s & 3.75 & 1.01 \\
\hline 20 & Reputation of a supplier & 3.74 & 1.25 \\
\hline 21 & The supplier has quality management systems in place & 3.73 & 1.22 \\
\hline 22 & Upliftment/empowerment of small organisations & 3.72 & 1.19 \\
\hline 23 & Supplier offers competitive prices & 3.72 & 1.24 \\
\hline 24 & Product is fashionable & 3.72 & 1.36 \\
\hline 25 & Supplier offers a broad range of products & 3.58 & 1.26 \\
\hline 26 & Origin of the product & 3.55 & 1.31 \\
\hline 27 & Our history with the supplier & 3.43 & 1.30 \\
\hline 28 & Supplier accepts product returns if there is product failure & 3.43 & 1.44 \\
\hline 29 & Locally manufactured crafts & 3.33 & 1.34 \\
\hline 30 & Products are packaged according to our requirements & 3.33 & 1.37 \\
\hline 31 & The supplier provides us with product and organisation information & 3.32 & 1.35 \\
\hline 32 & Supplier provides after-sales service/support & 3.14 & 1.48 \\
\hline 33 & Suggested retail price & 3.03 & 1.44 \\
\hline 34 & Products have a swing tag with information & 2.81 & 1.43 \\
\hline 35 & Supplier provides marketing support & 2.72 & 1.35 \\
\hline 36 & Financial position of the supplier & 2.57 & 1.48 \\
\hline 37 & Supplier provides product training & 2.53 & 1.42 \\
\hline 38 & Products are certified by authorised organisations, i.e. SABS, proudly SA & 2.51 & 1.55 \\
\hline 39 & Products are branded & 2.36 & 1.43 \\
\hline
\end{tabular}

Some supplier selection criteria were regarded as more important than others. The 10 supplier selection criteria considered most important, based on mean value in order of importance, were: 'product quality' $(M=4.59, S D=0.71)$, 'product is exciting' (M=4.39, $\mathrm{SD}=0.74)$, 'product styling and design' ( $M=4.18, \quad S D=0.87)$, 'product distinctiveness/uniqueness' $(M=4.18, S D=0.90)$, 'supplier's willingness to cooperate with us' $(M=4.18, S D=0.97)$, 'product's sales potential' (M4.17, SD=0.93), 'the ability to supply products based on our demand/requirements' $(M=4.15$, $\mathrm{SD}=0.92)$, 'supplier capacity' ( $\mathrm{M}=4.13, \mathrm{SD}=0.99)$, 'delivery reliability' $(\mathrm{M}=4.12, \mathrm{SD}=1.17)$ and 'total costs of acquiring the product' ( $M=4.08, S D=0.99)$, which were also very important. The five supplier selection criteria rated least important were: 'products are branded', 'products are certified by authorised organisations such as SABS or Proudly SA', 'supplier provides product training', 'financial position of a supplier' and 'supplier provides marketing support'. 'Products are branded' ( $M=2.36, S D=1.43$ ) was least important to craft retailers, followed by 'products are certified by authorised organisations such as $S A B S$ or Proudly $S A$ ' $(M=2.51, S D=1.55)$, 'supplier provides training' $(M=2.53, S D=1.2)$, 'financial position of a supplier' ( $M=2.53, S D=1.42)$ and 'supplier provides marketing support' ( $M=2.72, S D=1.35)$. 
The finding that product quality was considered the most important criterion is in line with previous studies on supplier selection criteria that also identified it as the most important criterion (Kim \& Boo, 2010:512; Skallerud \& Gronhaug, 2009; UNIDO, 2007; Government of Canada, 2005; Craft Council of Ireland, 2001:16; Hansen, 2001). Francis and Brown (1985-6) reported that organisations buying products that are difficult to measure or specify, such as crafts, are more concerned about quality than price, as evident in the findings for craft products with product quality ranking first and price only $33^{\text {rd }}$. Hansen (2001) found product quality, reliability and product returns to be the most important supplier selection criteria for supermarkets buyers. Furthermore, USAID (2008) found quality, price and timely delivery to be the most important criteria for retailers. However, this study found reliability to be the ninth most important supplier selection criterion and product returns the $28^{\text {th }}$ most important, which confirms that criteria differ for different types of products and organisations. A study investigating Tanzanian craft retailers also listed quality as the most important criterion that craft retailers in Tanzania look for, which strongly supports the finding that quality is critical for craft retailers (Belgian Development Agency, 2012).

It is argued, furthermore, that product quality is more important for buyers who are selecting suppliers for the first time (Kim \& B00, 2010). The relatively low importance attached to branding in this study is in line with findings from Hansen (2001), who also reported that branding is less important for buyers. Marketing support was found to be more important for up-market stores than for middle-range stores that consider it only of moderate importance (Skallerud \& Gronhaug, 2009).

\subsection{Hypothesis testing}

This hypothesis focuses on the significant differences between the years of buying experience of craft retailers and the importance they attach to supplier selection criteria. While it is important for craft producers to understand the supplier selection criteria craft retailers use to evaluate their suppliers, it is also important to understand the importance attached to different supplier selection criteria for different types of craft retailers with different years of buying experience. Thus, the hypothesis was formulated as follows:

$\mathrm{H}_{0}$ There are no significant differences between craft retailers' years of buying experience and the importance they attach to supplier selection criteria

$\mathrm{H}_{1}$ There are significant differences between craft retailers' years of buying experience and the importance they attach to supplier selection criteria

MANOVA testing was conducted and the Wilks' Lambda value of 0.71 is greater than $p<0.05$, indicating that there was no significant difference between years of buying experience and the importance craft retailers attached to selected evaluative criteria: $F(57,609)=1.28, p=0.086$; Wilks' Lambada $=0.71$. Therefore the null hypothesis was accepted. This implies that the years of buying experience do not play a role in the importance craft buyers attach to the supplier selection criteria. This finding concurs with Johansson and Burt, (2004), who reported that the experience of a buyer is only important when buyers select suppliers from the existing supply relationships and not when looking for new ones. Furthermore, Farrell (2006) found that criteria used by import buyers differed with years of buying experience. The buying experience was found to apply mainly in the rebuy situation (Mawson \& Fearene, 1997), which supports the findings that years of buying experience do not influence the criteria used by craft retailers.

\section{Discussion and Conclusion}

The ten most important supplier selection criteria were listed, in order of importance, as quality, the fact that the product is exciting, product styling and design, product distinctiveness/uniqueness, the supplier's willingness to cooperate with retailers, the product's sales potential, the ability to supply products based on retailers' demand/requirements, supplier capacity, delivery reliability and the total costs of acquiring the product. Craft producers should incorporate these criteria into their marketing strategy. They should also make sure that each of these important criteria is acted upon by incorporating those criteria that are product-related, such as quality, the fact that the product is exciting, product styling and design and product distinctiveness/uniqueness, into the product during the new product's development stages. They could also incorporate criteria such as the ability to supply products based on retailers' demand/requirements, supplier capacity, delivery reliability and total costs of acquiring the product into their distribution and pricing strategy, by ensuring that the right product, at the right time, at the right place and at the right price is delivered to the retailers. Craft producers could also use the ten most important supplier criteria to position their organisations and products against their competitors.

While price has been considered the most important criterion by some researchers (Lin \& Wu, 2011; Sternquist \& 
Chen, 2006; Dandeo, Fiorito, Giunipero \& Pearcy, 2006; Da Silva, Davies \& Naude, 2002; Esbjerg \& Skytte, 1999), craft retailers in this study considered other factors more important.

The least important supplier selection criteria are that products are branded, products are certified by authorised organisations such as SABS or Proudly SA, the supplier provides product training, the financial position of a supplier and that the supplier provides marketing support. Craft producers should thus place less emphasis on these criteria than on the most important ones. Again this is advantageous to the small craft producers lacking financial resources as they do not need to go through the often lengthy and expensive process of gaining certification for the products or providing marketing support that could be expensive.

It is interesting to note that product quality was rated the most important supplier selection criterion, yet having products certified by authorised organisations such as SABS or Proudly SA was indicated as the second least important supplier selection criterion. According to Cawley, Gaffey and Gilmore (1999), product quality can be achieved through certification in terms of possession of a quality mark or symbol, possession of a regional label and specification in terms of production delivery and traceability or link to a culture, and attractiveness in terms of design, texture, appearance, price and personal attention. When marketing their products some organisations emphasise quality features such as those that specify responsible use of natural environment or quality marks and certification of products (McDonagh \& Commins, 2000), yet some craft retailers do not consider certification an important criterion. Larger craft producers with more resources could apply for certification of their products through relevant bodies such as the SABS, and use this as a quality indicator when selling to retailers. They could also seek the governmental support required to quality assure their products.

Craft retailers consider the total cost of acquisition rather than price alone. This is shown by the fact that the total cost of ownership is rated the $10^{\text {th }}$ most important supplier selection criterion, whereas price is ranked $33^{\text {rd }}$ in level of importance. However, craft retailers buy from suppliers who are willing to negotiate prices (11 ${ }^{\text {th }}$ most important of all criteria) and also evaluate the price competitiveness of craft producers (23 $3^{\text {rd }}$ most important criterion). Craft retailers visit remote areas, driving as far as 1000 kilometres looking for craft producers, some of them camping at places near craft producers to acquire stock (Mutua, Massimo \& Mburu, 2004). This is possibly why total costs of ownership are more important than price alone. Therefore, there must be more focus on the total cost of ownership by the craft producers when setting their prices. Craft producers must also be willing to negotiate prices since this is very important to craft retailers.

Since product branding was rated the least important of the supplier selection criteria, craft producers could focus on other product-related criteria rather than branding when developing new products. The reason for the low importance accorded to branding may be that certain craft products, such as jewellery and wooden products, do not need the attachment of a name to enhance their appeal, while some retailers such as Mr Price sell their products under their house brand. However, it would be unwise for craft producers to ignore branding entirely, since a brand name is able to contribute to the recognition of the craft producer.

The fact that the number of years of buying experience was found not to play a role in the importance attached by craft retailers to selected evaluative criteria implies that craft producers could sell to retailers regardless of their years of buying experience.

The main limitation of this research is that convenience sampling was used and owing to the nature of nonprobability sampling, the results are not representative of the broader SA formal craft retail population. Therefore, the results cannot be generalised. Since the research adopted a convenience sampling method, the non-response error and the sampling error could not be determined. Only craft retailers that were easily accessible were targeted.

\section{References}

Belgian Development Agency. (2012). Market research on handicraft products in East Africa-Tanzania. Ipsos Marketing, The Innovation and Brand Marketing Specialists. Accessed 15 November 2013 at http://www.befair.be/sites/default/files/all-files/report-andimpact-studies/2012_Handicraft\%20Industry\%20in\%20 Tanzania,\% 20by\%20 T4DC.pdf.

Braglia, M. \& Petroni, A. (2000). A quality assurance oriented methodology for handling trade-offs in supplier selection. International Journal of Physical Distribution \& Logistics Management, 30(2),96-111.

Cawley, M.E., Gaffey, S.M., \& Gilmor, D. A. (1999). The Role of Quality Tourism and Craft SMEs in Rural Development: Evidence from the Republic of Ireland, Anatolia, 10(1),45-60.

Da Silva, R., Davies, G., \& Naude, P. (2002). Assessing the influence of retail buyer variables on the buying decision-making process. European Journal of Marketing, 36(11/12),1327-1343.

Da Silva, R., Davies, G., \& Naude, P. (2000). Marketing to UK retailers: Understanding the nature of UK retail buying of textiles and clothing. Journal of Fashion Marketing and Management, 4(2),162-172. 
Dempsey, W.A. (1978). Vendor selection and the buying process. Industrial Marketing Management, 7, 256-267.

Department of Labour. (2008). The creative industries in South Africa: Sector studies research project. Accessed 15 November 2013 at http://www.labour.gov.za/DOL/ downloads/documents/research-documents/ Creative\% 20Industries DoL Report.pdf.

Department of Sports, Arts, Recreation \& Culture. (2007). Final draft Gauteng Craft Audit Report, October 2007. Gauteng ,South Africa.

Department of Trade \& Industry. (2005). Sector Development Strategy: Craft. South Africa. Accessed 15 November 2013 at http://www.ccdi.org.za/research-and-publications/research/ Customised\% 20 Sector\%20Programme\%20for\%20Craft.pdf.

Design Africa. (2008). SIAO presentation. November. http://www.agoatoolkit.com/ agoa/English/Select\%20Products/Handicraft/ Handicrafts\%20Export\%20Guides/05.pdf.

Ettenson, R. D., \& Wagner, J. (1986). Retail buyers' saleability judgements: a comparison of information use across three levels of experience. Journal of Retailing, 62(1),41-62.

Fiorito, S.S. (1990). Testing a portion of Sheth's theory of merchandise buying behaviour with small apparel retail firms. Entrepreneurship Theory and Practice, Summer, 19-34.

Francis, S.K., \& Brown, D.J. (1985-86). Retail buyers of apparel and appliances: a comparison. Clothing and Textile Research Journal, $4(1), 1-8$.

Grobler, A.T. (2005). Product development for community-craft projects in Mpumalanga. An unpublished masters dissertation, University of Pretoria.

Hansen, K. (2001). Purchasing decision behaviour by Chinese supermarkets. International Review of Retail, Distribution and Consumer Research,11(2),159-175.

Hansen, T.H. \& Skytte, H. (1997). Retailers' choice of suppliers and products. Working paper No 49, March.

Hay, D. (2008). The business of craft and crafting the business: Strategies for success in the rural craft sector, 1-60. Accessed 15 November 2013 at http://www.tcd.ufl.edu/Data/Sites/44/media/documents/tropilunch/2011/BusinesofCraftHandbooklowresolution.PDF.

Johansson, U., \& Burt, S. (2004). The buying of private brands and manufacturer brands in grocery retailing: A comparative study of buying processes in the UK, Sweden and Italy. Journal of Marketing Management, 20(7-8),799-824.

Kahraman, C., Cebeci, U., \& Ulukan, Z. (2003). Multi-criteria supplier selection using fuzzy AHP. Logistics Information Management, $16(6), 382-394$.

Kaiser \& Associates. (2005). Craft first paper. The Scope of the Craft Industry in the Western Cape. Accessed 15 November 2013 at http://www.weterncape.gov.za/ other/2005/11/final_first_paper_craft.pdf.

Kim, M., \& Boo, S. (2010). Understanding supplier selection criteria: Meeting planner's approaches to selecting and maintaining suppliers. Journal of Travel \& Tourism Marketing, 27(5), 507-518.

Lin, P.C \& Wu, L.S. (2011). How supermarket chains in Taiwan select suppliers of fresh fruit and vegetables via direct purchasing. The Service Industries Journal, 31(8), 1237-1255.

Littrell, M.A., \& Miller, N.J. (2001). Marketing across cultures. Journal of Global Marketing, 15(1),67-86.

Luo, X., Wu, C., Rosenburg, D., \& Barnes, D. (2009). Supplier selection in agile supply chains: An information processing model and an illustration. Journal of Purchasing and Supply Management, 15, 249-262.

Luutonen, M. (2009). Handmade marketing. Proceedings of the crafticulation and education conference. Research in Sloyd Education and Craft Science A, 14, 119-127. Accessed 15 November 2013 at https://helda.helsinki.fi/bitstream/handle/10224/ 4810/Kaukinen_verkko .pdf?sequence=2.

Makhitha, K.M., \& Bresler, N. (2011). The perceived marketing benefits of the 2010 FIFA World Cup for craft businesses. African Journal for Physical, Health Education, Recreation and Dance (Supplement), 232-252.

Malhotra, N.K.( 2010). Marketing research: An applied orientation. (6th Ed.). Pearson.

Mawson, E., \& Fearne, A. (1997). Organizational buyer behaviour: a study of UK restaurant chains. British Food Journal, 99(7),239-243.

McCarthy, A \& Mavundla, K. (2009). Craft as an economic enterprise: Strategies for alternative livelihoods in Kwazulu-Natal. Small Enterprise Development Agency (SEDA), 5(1):34-42. Accessed 15 November 2013 at http://www.seda.org.za/ Publications/ Publications/SEDA\%20SBM\%202009.pdf.

McLaughlin, E.W. \& Rao, V.R. (1990). The strategic role of supermarket buyer intermediaries in new product selection: implications for system wide efficiency. American Journal of Agricultural Economics, May.

Mutua., K., Massimo, S.K. \& Mburu, P.T. (2004). An Empirical Study of the Botswana Handicraft Market. Journal of African Business, 5(2),93-112.

Nilsson, J. (1977). Purchasing by Swedish grocery chains. Industrial Marketing Management, 6,317-328.

Park, D. \& Krishna, H.A. (2001). Supplier selection practices among small firms in the United States: Testing the three models. Journal of Small Business Management, 39(3),259-271.

Rogerson, C.M. (2000). Successful SMEs in South Africa: The case of clothing producers in the Witwatersrand. Development Southern Africa, 17(5),687-716.

Sheth, J.N. (1981). A theory of merchandise buyer behaviour. Faculty working papers, College of Commerce and Business Administration, University of Illinois at Urbana-Champaign, August 29. Accessed 15 November 2013 at https://www.ideals. illinois.edu/bitstream/handle /2142/ 27923/theoryofmerchand706shet.pdf?sequence=1.

Skallerud, K., \& Gronhaug, K. (2010). Chinese food retailers' positioning strategies and the influence on their buying behaviour. Asia Pacific Journal of Marketing and Logistics, 22(2),197-209.

Sternquist, B. \& Chen, Z. (2006). Food retail buyer behaviour in the People's Republic of China: a grounded theory model. Qualitative 
market Research: An International Journal. 9(3),243-265.

UNIDO. (2007). Creative industries and micro \& Small Scale Enterprise Development: A Contribution to Poverty Alleviation. Project XP/RAS/05/002 As a Joint Initiative by UNIDO and UNESCO. Private Sector Development Branch Programme Development and Technical Cooperation Division. Accessed 15 November 2013 at http://www.unido.org/ fileadmin/user_media/Publications/ Pub_free/69264_creative_industries.pdf.

Urban-Econ Tourism. (2010). Feasibility Study for Umbumbulu Arts and Crafts Trade Centre. Quotation 38DED/2008. Accessed 15 November 2013 at http://www.kznded.gov.za/ Portals/0/ 24.01.10\% 20 Umbumbulu\%20Craft\%20Centre.pdf.

USAID. (2008). Handcraft sector in Aqaba: Diagnostic strategy and action plan. Aqaba Community and Economic Development Program (ACEP). September, 24. Accessed 15 November 2013 at http://www.aced-jordan.com/files/publication_attachments/ Handicraft\% 20Sector\%20in\%20Aqaba\%20\%E2\%80\%93\%20Diagnostic,\%20Strategy\%20and\%20Action\%20Plan(publish).pdf.

USAID. (2006). Global market assessment for handicrafts. Vol. 1, Final Draft, July. Accessed 15 November 2013 at http://pdf.usaid. gov/pdf_docs/PNADN210.pdf.

Wagner, J., Ettenson, R. \& Parrish, J. (1989). Vendor selection among retail buyers: an analysis by merchandise division. Journal of retailing, 65(1),58-79.

Webster, F.E., \& Wind, Y. (1996). A general model for understanding organizational buying behaviour. Marketing Management, ABI/INFORMWinter/Spring, 4(4),52-57.

Wilson, E.J. (1994). The relative importance of supplier selection criteria: a review and update. International Journal of Purchasing and Materials Management, summer,35-41.

Yu, H., Fairhurst, A.E., \& Lennon, S.J. (1996). Small retail store buyers' response to apparel markets. Journal of Small Business Management, 14-22. 